\title{
ANNOUNCEMENT
}

\section{Achieving Climate Predictability Using Paleoclimate Data \\ EuroConference on Abrupt Climate Change Dynamics}

\begin{abstract}
Castelvecchio Pascoli, Italy, 10-15 November 2001
With the growing awareness that the Earth's climate system can shift abruptly, and without warning, from one climate state to another comes the imperative to develop the scientific understanding needed to anticipate climate "surprises" of the future. Although this meeting will include some consideration of large glacial events, the primary focus will be on "warm climate" (interglacial) abrupt change. The paleoclimate record makes it clear that abrupt climate shifts known to have occurred in the 20th century are only a subset of possible surprise climate system behaviors that have occurred in the more distant past and might be expected to occur in the future. Goals of the meeting are to summarize state of the art and guide efforts to answer priority questions regarding abrupt climate change dynamics. Deadline for applications is August 15, 2001.

For information and application forms, please contact the Head of the EURESCO Unit:
\end{abstract}

Dr. J. Hendekovic

European Science Foundation

1 quai Lezay-Marnésia

67080 Strasbourg Cedex, France

Telephone: +33388767135

Fax: +33 388366987

E-mail: euresco@esf.org

http://www.esf.org/euresco 